\title{
Perception and Factors Influencing Compliance to Drug Regimen among HIV/Aids Patients Attending Antiretroviral Therapy Clinic in University Of Medical Sciences Teaching Hospital, Ondo State, Nigeria
}

\author{
Mary Idowu Edward, Folakemi Beatrice Adumaza, Esther Olayinka Awosika, Atilola Oluwatobi \\ Adekunle
}

\begin{abstract}
Nigeria has the second largest HIV epidemic in the world. The development and widespread use of antiretroviral drugs in the developed countries leads to transformed perception of HIV/AIDS from fatal incurable disease to a manageable chronic illness. The treatment causes improvement in immunological status and a reduction in viral loads, thus reducing the incidence of hospitalization and mortality. The treatment effectiveness requires a high level of compliance and this can lead to devastating public health problems. The objective of this study was to assess the perception and factors influencing compliance to drug regimen among HIV/AIDS positive patients attending anti-retroviral therapy clinic in University of Medical Science Teaching hospital Akure. A descriptive type of non-experimental design was adopted to investigate the research variables among 80 respondents selected using convenient sampling technique. A self-developed questionnaire was used for data collection and same analyzed using descriptive and Statistical Package for Social Sciences (SPSS) version 24. Results showed that $81.3 \%$ respondents had good perception about antiretroviral therapy, $96.3 \%$ respondents had good compliance with use of their antiretroviral drugs and some of the factors influencing compliance include side effects of the drugs, forgetfulness, drugs being too many and attitude of care providers. There is a significant relationship between level of education and perception about antiretroviral therapy $(d f=4, p<0.001)$, likewise significant relationship exists between perception and compliance with antiretroviral therapy $(\mathbf{d f}=\mathbf{1}, \quad \mathrm{p}<0.001)$. Therefore, nurses and other health care providers at the clinics should maintain a positive accommodating attitude towards patients as this was a major deterrent to the compliance practices among respondents in the study.
\end{abstract}

Index Terms - Antiretroviral Therapy Clinic,Compliance, Factors, HIV/AIDS positive patients, Perception.

\section{INTRODUCTION}

According to the joint United Nations programme on

Mary Idowu Edward, Faculty of Nursing Science, University of Medical Sciences, Ondo State, Nigeria

Folakemi Beatrice Adumaza, Masters program in Adult Health Nursing at Babcock University Ilishan Ogun State

Esther Olayinka Awosika, Masters program in mental health Nursing at Nnamdi Azikiwe University Awka

Atilola Oluwatobi Adekunle, BNSc.Degree Program in Ladoke AkintolaUniversity, Osun State
HIV/AIDS report,women and girls in sub-Saharan Africa continue to be the most affected and accounted for $59 \%$ of all new HIV infections in the region in 2019, with 4500 adolescent girls and young women between 15 and 24 years old becoming infected with HIV every week. Young women accounted for $24 \%$ of new HIV infections in 2019(UNAIDS, 2020).. Nigeria has $10 \%$ of the global burden of HIV/AIDS and had HIV prevalence rate of 3.0\% in 2014.Nigeria has the second largest HIV epidemic in the world. (NACA, 2020).

Global coverage of antiretroviral therapy reached $46 \%$ $(43-50 \%)$ at the end of 2015. Gains were greatest in the worlds most affected region, eastern and southern Africa. Coverage increased from $24 \%(22-26 \%)$ in 2010 to $54 \%$ $(50-58 \%)$ in 2015 , reaching a regional total of 10.3 million people. South Africa alone had nearly 3.4 million people on treatment, more than any other country in the world. Next to South Africa is Kenya, which has the largest treatment programme in Africa, with nearly 900000 people on treatment at the end of 2015. Botswana, Eritrea, Kenya, Malawi, Mozambique, Rwanda, South Africa, Swaziland, Uganda, the United Republic of Tanzania, Zambia and Zimbabwe all increased treatment coverage by more than 25 percentage points between 2010 and 2015. Western and central Africa and the Middle East and North Africa also made important gains but achieved lower levels of coverage in 2015, 28\% $(23-34 \%)$ and $17 \%(12-24 \%)$, respectively. Treatment coverage in other regions of the world like the Latin American, the Caribbean, the Asia and Pacific region were also more than doubled, in 2015 (UNAIDS 2016)

The primary target of HIV is T-4 helper cells, a sub-population of lymphocytes that is essential for body's defence against disease. HIV infects and kills T-4 helper cells, thereby disrupting communication within the cellular immune system with consequent development of wide spread opportunistic infections often caused by microbes of relatively low pathogenicity. Extensive laboratory and epidemiological shows that blood and blood product, semen and vaginal / cervical secretions are important in transmission of HIV (Wilson, 2020).

There is no cure or vaccine for HIV, however, antiretroviral treatment can slow course of the disease and 
may lead to a near normal life expectancy. The incubation period is long, up to 6 years and more. HIV infection is presumably lifelong and the risk of illness may continue throughout life of infected persons. The infected person may be asymptomatic for long period, they are nevertheless capable of transmitting HIV (Wilson, 2020) Adherence to ART is a determinant of viral suppression and risk of transmission, disease progression but suboptimal adherence has been a major challenge associated with a diversity of patient- and programme-related challenges.

Treatment adherence describes the degree to which a patient correctly follows medical advice. It mostly refers to medication compliance, but it is also referred to in situations like medical device use, self-care, self-directed exercises, or therapy sessions. ART adherence corresponds to the ability to comply with ART medication prescribed and provided in the clinic for at least $95 \%$ of the time. Compliance may be affected both by the patient and the health-care provider, and a positive physician-patient relationship has great impact on compliance improvement (Mehari, Kiros, Yemane, Asghedom, Debesay, \& Tekeste, 2017),

ART decreases the total burden of HIV in patients, maintains their immune system function, and prevents opportunistic infections occurrence that often causes death. Adherence to ART is a key factor to prevent treatment failure in most patients infected with HIV. A significant association between medication adherence and viral suppression was reported in patients subjected to the treatment of HIV. Remarkably, defaulting from treatment is one of the most critical problems in the management of HIV/AIDS. Low adherence can result in cross resistance to other antiretroviral drugs (Masikini, \& Mpondo, 2015).

Perception is an individual's awareness, insight and opinion about a situation. HIV/AIDS patient perception about antiretroviral drugs is a legitimate indicator of the level of compliance. How they perceive the drug determines their level of compliance. If patients perceive antiretroviral drugs as helping, easy to take, convenience, no serious side effects, they will be motivated to be more compliant, come for medical check-up and take their drugs regularly. If they have low perception about the drug, the reverse will be the case.Compliance is facilitated when patient are motivated to take their drugs and have desire to comply.

Factors affecting ART adherence include patient characteristics, ART regimen, clinical setting, social and environmental factors, and the relationship between patients and their health care providers (Shigdel, Klouman, Bhandari, Ahmed, (2014). Generally, there is treatment failure and increased hospitalization whenever adherence is compromised, which significantly affects the quality of life (Mehari et al 2017). Adherence to ART is a determinant of viral suppression and risk of transmission, disease progression but suboptimal adherence has been a major challenge associated with a diversity of patient- and programme-related challenges. Hence this research aimed to assess the factors which contributed more to treatment adherence and factors hindering patients from acceptable adherence level.Non adherence to HAART can lead to inadequate suppression of viral replication, continued destruction of CD4 cells, progressive decline in immune function and disease progression. In public health interest, drug resistance can develop and be transmitted to other person during high risk activity which limit therapeutic options in the future. According toClutter, et al, (2016).HIV drug resistance (HIVDR) poses a potential threat to the long-term success of ART and is emerging as a threat to the elimination of AIDS as a public health problem by 2030 .

The critical factors that influence adherence falls into four main categories: patient factors such as use of drugs and alcohols, age, sex, cultural beliefs or ethnicity; medication regimen such as dosing complexity, side effects, number of pills or food requirements; patient-health care provider relationship and the system of care. Patient's behaviour is the critical link between a prescribed regimen and treatment outcome. When the patient refuses to take the drug as prescribed, the treatment therefore will fail to achieve its purpose.

\section{A. Study Objectives}

1. To determine the perception of antiretroviral therapy among HIV/AIDS patients.

2. To estimate the level of compliance to anti-retroviral therapy.

3. To identify the factors affecting adherence to anti-retroviral therapy by HIV positive patients.

\section{B. Hypothesis}

1. There is no significant relationship between level of education and perception about antiretroviral therapy

2. There is no relationship between perception and compliance with antiretroviral therapy

\section{METHODS AND MATERIALS.}

\section{A. Design}

A descriptive type of non-experimental design was adopted to know the factors affecting adherence to anti-retroviral therapy in the study population and to determine the accessibility of HIV/AIDS patients to antiretroviral facilities.

\section{B. Study Population}

The study population for this study was HIV patients attending Anti-retroviral clinic in University of medical science teaching hospital, Akure

\section{Sampling size and sampling technique}

Convenience sampling techniques was used in selecting the sample for this study. This is a sampling technique where questionnaires are purposely distributed to HIV patients attending Anti-retroviral clinic in UNIMEDTH Akure.

\section{Instrument Used for Data Collection}

A self-developed questionnaire was used by the researcher. The questions was closed ended questions so as to attract the 
best response from the subjects. The questionnaires consist of four sections. This questions were designed to elicit information from the respondents about the perception and factors that affect the adherence to antiretroviral therapy in HIV infected patients attending clinic in university of medical sciences teaching hospital Akure. Section A: -Demographic data, Section B: - Perception to antiretroviral therapy, Section C: - Adherence to antiretroviral therapy and Section D: factors affecting adherence to antiretroviral therapy

\section{E. Method of Data Analysis}

Data was analysed using Statistical Package for Social Sciences (SPSS) and other statistical analysis consisting of frequency and percentage tables and charts.

\section{F. Ethical Consideration}

A proposal of the study was submitted to the UNIMED for ethical review. A letter requesting for permission to conduct study was obtained from the school authority.Participants were made to understand the purpose of the study.Informed consent was obtained from all interested participants and all information gotten was

treated with confidentiality.No participant was forced to respond to questionnaire.

\section{RESULTS}

\section{A. Socio-Demographic Data of the Respondents}

The result in the above table shows the age of 80 respondents, $17.5 \%$ of the respondents were between 21-30 years, $27.5 \%$ were within $31-40$ years, $30 \%$ of the respondents were between 41-50 years and 25\% of the respondents were 51 years and above. Distribution of respondents according to sex shows that $41.25 \%$ of the respondents were male and $58.75 \%$ were female. Distribution of respondents according to religion shows that $32.5 \%$ were Muslims and $67.5 \%$ were Christians.

Distribution according to their level of education shows that $22.5 \%$ of the respondents were primary school certificate holders, $52.5 \%$ were secondary school certificate others, $50 \%$ studied up to OND/HND, $17.4 \%$ were degree/post graduates and $2.5 \%$ had no formal education. Distribution according to ethnicity showed that $72.5 \%$ of the respondents were Yoruba, $7.5 \%$ were Ibo and $20 \%$ of the respondents were from other ethnic groups. Distribution according to marital status showed that $22.5 \%$ of the respondents were single and $77.5 \%$ were married. Distribution according to occupation showed that $2.5 \%$ of the respondents were students, $20 \%$ were civil servants and 77.55 were self-employed

Table 1: Demographic data

\begin{tabular}{|c|c|c|c|}
\hline VARIABLE & RESPONDENTS & FREQUENCY $(\mathrm{N}=80)$ & $\begin{array}{l}\text { PERCENTAGE } \\
(100 \%)\end{array}$ \\
\hline AGE & $\begin{array}{l}21-30 \\
31-40 \\
41-50 \\
51 \text { and above } \\
\end{array}$ & $\begin{array}{l}14 \\
22 \\
24 \\
20\end{array}$ & $\begin{array}{l}17.5 \% \\
27.5 \% \\
30 \% \\
25 \% \\
\end{array}$ \\
\hline SEX & $\begin{array}{l}\text { Male } \\
\text { Female }\end{array}$ & $\begin{array}{l}33 \\
47 \\
\end{array}$ & $\begin{array}{l}41.25 \% \\
58.75 \%\end{array}$ \\
\hline RELIGION & $\begin{array}{l}\text { Christianity } \\
\text { Muslim } \\
\text { Traditional } \\
\text { Others }\end{array}$ & $\begin{array}{l}54 \\
26 \\
0 \\
0\end{array}$ & $\begin{array}{l}67.5 \% \\
32.5 \% \\
0 \\
0\end{array}$ \\
\hline $\begin{array}{l}\text { EDUCATIONAL } \\
\text { LEVEL }\end{array}$ & $\begin{array}{l}\text { Primary } \\
\text { Secondary } \\
\text { OND/HND } \\
\text { Degree/Post graduate } \\
\text { None }\end{array}$ & $\begin{array}{l}18 \\
42 \\
4 \\
14 \\
2\end{array}$ & $\begin{array}{l}22.5 \% \\
52.5 \% \\
5 \% \\
17.5 \% \\
2.5 \%\end{array}$ \\
\hline ETHNICITY & $\begin{array}{l}\text { Yoruba } \\
\text { Igbo } \\
\text { Hausa } \\
\text { Others }\end{array}$ & $\begin{array}{l}58 \\
6 \\
0 \\
16 \\
\end{array}$ & $\begin{array}{l}72.5 \% \\
7.5 \% \\
0 \\
20 \%\end{array}$ \\
\hline MARITAL STATUS & $\begin{array}{l}\text { Single } \\
\text { Married } \\
\text { Divorced }\end{array}$ & $\begin{array}{l}18 \\
62 \\
0\end{array}$ & $\begin{array}{l}22.5 \% \\
77.5 \% \\
0\end{array}$ \\
\hline OCCUPATION & $\begin{array}{l}\text { Student } \\
\text { Civil servant } \\
\text { Self-employed }\end{array}$ & $\begin{array}{l}2 \\
16 \\
62 \\
\end{array}$ & $\begin{array}{l}2.5 \% \\
20 \% \\
77.5 \% \\
\end{array}$ \\
\hline
\end{tabular}

\section{A. Perception of HIV/AIDS towards antiretroviral therapy}

The table above signifies that $100 \%$ of the respondents agree that, "Human immunodeficiency virus can occur due to exposure to infected objects, having unprotected sexual intercourse or having contact with the body fluid of person with HIV". Majority,97.5\% of the respondents also agreed that, "antiretroviral drugs is necessary to boost the immunity. All the respondents, $100 \%$ of the respondents agreed that, "the drugs needs to be taken as prescribed". $2.5 \%$ of the respondents agreed that, "you need the drugs only when you have symptoms", while $97.5 \%$ disagreed. Majority $90 \%$ of the respondents agreed that, "orthodox medicine can cure the disease", Majority, $77.5 \%$ of the respondents disagreed that, "traditional medicine can cure the disease.

Table 2: Perception of HIVAIDS towards antiretroviral therapy $(n=80)$ 
Perception and Factors Influencing Compliance to Drug Regimen among HIV/Aids Patients Attending Antiretroviral Therapy Clinic in University Of Medical Sciences Teaching Hospital, Ondo State, Nigeria

\begin{tabular}{|c|l|l|l|c|}
\hline Variable & $\begin{array}{l}\text { Agree } \\
\text { Freq. (\%) }\end{array}$ & $\begin{array}{l}\text { Disagree } \\
\text { Freq. (\%) }\end{array}$ & $\begin{array}{c}\text { Don't } \\
\text { Know } \\
\text { Freq. (\%) }\end{array}$ & kemar \\
\hline $\begin{array}{l}\text { Human immunodeficiency virus can occur due to } \\
\text { exposure to infected objects, having unprotected } \\
\text { sexual intercourse or having contact with the body } \\
\text { fluid of person with HIV }\end{array}$ & $80(100.0)$ & $0(0)$ & $(0)$ & Good \\
\hline $\begin{array}{c}\text { Antiretroviral drugs is necessary to boost the } \\
\text { immunity }\end{array}$ & $78(97.5)$ & $2(2.5)$ & $0(0)$ & Good \\
\hline The drugs need to be taken as prescribed & $80(100.0)$ & $0(0)$ & $(0)$ & Good \\
\hline You need the drugs only when you have symptoms & $2(2.5)$ & $78(97.5)$ & $0(0)$ & Good \\
\hline Orthodox medicine can cure the disease & $72(90.0)$ & $6(7.5)$ & $2(2.5)$ & Good \\
\hline Traditional medicine can cure the disease, & $2(2.5)$ & $62(77.5)$ & $16(20)$ & Good \\
\hline
\end{tabular}

\section{A. Adherence to antiretroviral therapy}

From the table above, it can be deduced that, $100 \%$ of the respondents takes their drug often. $77.5 \%$ indicated that they have never missed their drug and $22.5 \%$ of the respondents said to have missed their drugs. $100 \%$ of the respondents said, "I can cope with drugs as prescribed'. $100 \%$ of the respondents agreed that following their antiretroviral therapy plan is essential for the effectiveness of the antiretroviral drugs. All, $100 \%$ of the respondents also agreed that strict adherence to their treatment plan will help them to be healthy so they take their drugs as prescribed. While $2.5 \%$ of the respondents opined that the treatment plan is difficult to follow, $97.5 \%$ stated otherwise

Table 3: Adherence to antiretroviral therapy $(\mathbf{n}=\mathbf{8 0})$

\begin{tabular}{|c|c|c|c|c|c|}
\hline \multirow[b]{2}{*}{ VARIABLES } & \multicolumn{2}{|c|}{ YES } & \multicolumn{2}{|c|}{ NO } & \multirow[b]{2}{*}{ Remark } \\
\hline & Fre & $\%$ & Fre & $\%$ & \\
\hline I take my drugs often & 80 & $\begin{array}{l}100 . \\
0\end{array}$ & 0 & 0 & Good \\
\hline I have never missed my drugs & 62 & 77.5 & 18 & $\begin{array}{ll}22 \\
.5\end{array}$ & Good \\
\hline I can cope with drugs as prescribed & 80 & $\begin{array}{l}100 . \\
0\end{array}$ & 0 & 0 & Good \\
\hline $\begin{array}{l}\text { I know that following my antiretroviral therapy plan is } \\
\text { essential for the effectiveness of the antiretroviral drug }\end{array}$ & 80 & $\begin{array}{l}100 . \\
0\end{array}$ & 0 & 0 & Good \\
\hline $\begin{array}{l}\text { I realize that strict adherence to the treatment plan will help me } \\
\text { to be healthy so I take my drugs as prescribed }\end{array}$ & 80 & $\begin{array}{l}100 . \\
0\end{array}$ & 0 & 0 & Good \\
\hline The treatment plan is difficult to follow & 2 & 2.5 & 78 & $\begin{array}{l}97 \\
.5\end{array}$ & Good \\
\hline
\end{tabular}

D.Factors affecting adherence to antiretroviral therapy The table above shows that $7.5 \%$ of the respondents are affected by the drug when thy take them and $92.5 \%$ are not. $100 \%$ of the respondents are not scared of the side effects of the drugs when they take them.12.5\% of the respondents sometimes, forget to take their drugs and $87.5 \%$ do not forget. 2.55 of the respondents opined that the drugs are too many and $97.5 \%$ doesn't think the drugs are too many. $95 \%$ of the respondents agreed that the ART clinic is accessible and 55 of the respondents think the clinic is not accessible. Transport cost to ART clinic is affordable for $97.5 \%$ of the respondents and unaffordable for $2.5 \%$ of the respondents. $100 \%$ of the respondents agreed that the physical environment of the clinic is neat and welcoming. $17.5 \%$ of the respondents do not want to be seen at the clinic and $82.5 \%$ doesn't mind to be seen. $100 \%$ of the respondents agreed that the nature of their work has not been giving them enough time to attend the clinic. While, $2.5 \%$ of the respondents said that the workers are not accommodating, $97.5 \%$ of the respondents opined that the workers are accommodating. 
Table 4: Factors affecting adherence to antiretroviral therapy

\begin{tabular}{|c|c|c|c|c|}
\hline \multirow[b]{2}{*}{ VARIABLES } & \multicolumn{2}{|c|}{ YES } & \multicolumn{2}{|c|}{ NO } \\
\hline & Freq. & $\%$ & Fre & $\%$ \\
\hline The drug affect me when I take them & 6 & 7.5 & 74 & $\begin{array}{l}92 . \\
5\end{array}$ \\
\hline I am scared of the side effects of the antiretroviral drugs & 80 & $\begin{array}{l}100 . \\
0\end{array}$ & 0 & 0 \\
\hline Sometimes, I forget to take my drugs & 10 & 12.5 & 70 & $\begin{array}{l}87 . \\
5\end{array}$ \\
\hline The drugs are too many & 2 & 2.5 & 78 & $\begin{array}{l}97 . \\
5\end{array}$ \\
\hline The ART clinic is accessible & 76 & 95.0 & 4 & 5.0 \\
\hline Transport cost to ART is affordable & 78 & 97.5 & 2 & 2.5 \\
\hline The physical environment of the clinic appears neat and welcoming & 80 & $\begin{array}{l}100 . \\
0\end{array}$ & 0 & 0 \\
\hline I don't want to be seen at the clinic & 14 & 17.5 & 66 & $\begin{array}{l}82 . \\
5\end{array}$ \\
\hline $\begin{array}{l}\text { The nature of my work has not been giving me enough time to attend the } \\
\text { clinic }\end{array}$ & 80 & $\begin{array}{l}100 . \\
0\end{array}$ & 0 & 0 \\
\hline $\begin{array}{l}\text { I don't like taking my drugs regularly because of the side effects I } \\
\text { experience after taking the drugs }\end{array}$ & 80 & $\begin{array}{l}100 . \\
0\end{array}$ & 0 & 0 \\
\hline $\begin{array}{l}\text { I don't take my drugs regularly because I don't have enough money for } \\
\text { transportation to the clinic to collect my drugs as at when due }\end{array}$ & 80 & $\begin{array}{l}100 . \\
0\end{array}$ & 0 & 0 \\
\hline The workers are accommodating & 78 & 97.5 & 2.5 & \\
\hline
\end{tabular}

B. TESTING OF HYPOTHESES

1. There is no significant relationship between level of education and perception about antiretroviral therapy

Table 5: Relationship between level of education and perception about antiretroviral therapy using chi-square test

\begin{tabular}{|c|c|c|c|c|c|c|c|}
\hline \multirow{2}{*}{\multicolumn{2}{|c|}{ Variables }} & \multicolumn{3}{|c|}{ perception about antiretroviral therapy } & \multirow{2}{*}{$\begin{array}{c}\text { Chi-squar } \\
\text { e } \\
\end{array}$} & \multirow[t]{2}{*}{ df } & \multirow{2}{*}{$\begin{array}{c}\text { P-valu } \\
\text { e } \\
\end{array}$} \\
\hline & & Good & Poor & Total & & & \\
\hline \multirow{6}{*}{$\begin{array}{ll}\text { Level of } \\
\text { education }\end{array}$} & None & 0 & 2 & 2 & \multirow{6}{*}{28.180} & \multirow{6}{*}{4} & \multirow{6}{*}{0.000} \\
\hline & Primary & 8 & 10 & 18 & & & \\
\hline & Secondary & 39 & 3 & 42 & & & \\
\hline & OND/HND & 4 & 0 & 4 & & & \\
\hline & Degree/Postgraduate & 14 & 0 & 14 & & & \\
\hline & Total & 65 & 15 & 80 & & & \\
\hline
\end{tabular}

Table 5 shows that there is a significant relationship between level of education and perception about antiretroviral therapy $(\mathrm{df}=4, \mathrm{P}<0.001)$. There is no relationship between perception and compliance with antiretroviral therapy

Table 6: Relationship between respondents' perception and compliance with antiretroviral therapy

\begin{tabular}{|c|c|c|c|c|c|c|c|}
\hline \multirow{2}{*}{\multicolumn{2}{|c|}{ Variables }} & \multicolumn{3}{|c|}{ compliance with antiretroviral therapy } & \multirow{2}{*}{$\begin{array}{c}\text { Chi-squar } \\
\text { e }\end{array}$} & \multirow[t]{2}{*}{ df } & \multirow{2}{*}{$\begin{array}{c}\text { P-valu } \\
\text { e }\end{array}$} \\
\hline & & Good & Poor & Total & & & \\
\hline \multirow{3}{*}{$\begin{array}{l}\text { perception about } \\
\text { antiretroviral therapy }\end{array}$} & Good & 65 & 0 & 65 & \multirow{3}{*}{43.119} & \multirow{3}{*}{1} & \multirow{3}{*}{0.000} \\
\hline & Poor & 12 & 3 & 15 & & & \\
\hline & Total & 77 & 3 & 80 & & & \\
\hline
\end{tabular}

Table 6 shows that there is a significant relationship between perception and compliance with antiretroviral therapy $(\mathrm{df}=1$, $\mathrm{P}<0.001)$.

\section{DISCUSSION OF FINDINGS}

In the study, $17.5 \%$ of the respondents were between $21-30$ years, $27.5 \%$ were within $31-40$ years, $30 \%$ of the 


\section{Perception and Factors Influencing Compliance to Drug Regimen among HIV/Aids Patients Attending Antiretroviral Therapy Clinic in University Of Medical Sciences Teaching Hospital, Ondo State, Nigeria}

respondents were between 41-50 years and $25 \%$ of the respondents were 51 years and above. This finding was expected because there are no age prevalence in HIV distribution as it can affect any age group. $41.25 \%$ of the respondents were male and $58.75 \%$ were female. This finding was expected because literatures have published a strong higher prevalence of HIV in females than in male. A similar finding was observed in the study by Uchenna et al (2015) where 67.45 of the student respondents were females. In the study also, $32.5 \%$ were Muslims and $67.5 \%$ were Christians. This was expected because Christianity is the dominant religion in the southwestern part of Nigeria as opposed to that seen in the northern part and this can be attributed to the wide spread and acceptance of Christianity in this region.72.5\% of the respondents were Yoruba, $7.5 \%$ were Ibo and $20 \%$ of the respondents were from other ethnic groups. Again this is not a surprising finding because the research setting is located in an Yoruba dominated settlement in Ondo state one that can be described as the heart of the Yoruba clan.

In the study, 65(81.3\%) respondents had good perception about antiretroviral therapy while $15(18.7 \%)$ had poor perception about it. This reflects a significant deficit which may adversely hamper compliance with antiretroviral drugs among the respondents. This finding was in keeping with that observed in the study by van Paasschen, Bacci, \& Melcher (2015) where $97.2 \%$ of respondents had positive perception about ART. These findings call on

the nurses and HIV counselors in the HIV clinics to engage HIV positive patients in meaningful educational section that will improve their perception and consequently their overall compliance with their ART.

In the current study, 77(96.3\%) respondents had good compliance with use of their antiretroviral drugs while $3(3.7 \%)$ had poor compliance with it. This finding was not expected considering the significantly level of poor perception observed in the study; however, this shows that patients are very compliant with their treatment plans. This finding was in keeping with that observed in the study by Gbadebo (2017) on people living with human immunodeficiency virus (HIV) and attending the ART service at HiwotFana and Jugal hospitals where the magnitude of adherence to ART in the week before interview was $87 \%$. A similar finding was observed in the study by Mukesh et al (2017) on non-adherence to antiretroviral therapy among people living with HIV/AIDS attending two tertiary care hospitals in district of Northern India where a total of $10.9 \%$ of patients were found to be non-adherent to ART. A contrasting finding was observed in the study by Okoronkwo, et al (2013) where a high non-adherence rate of $85.1 \%$ was observed.

Findings from this study shows that all the patients attending ART clinic in University of Medical Sciences Teaching Hospital, Akure complex adhered to their therapy as $100 \%$ of the respondents claimed to take their drugs often which was supported by Martin and Cacho, 2008 who stated that $80 \%$ of adherence to the therapy is required to guarantee treatment effectiveness. All, $100 \%$ of the respondents agreed that strict adherence to the treatment plan is essential for the effectiveness of the antiretroviral drug which was supported by Nega, Taye, Million, et al. (2020), who stated that poor adherence to antiretroviral therapy can lead to clinical, immunological and virological failure which will later result into the spread of drug resistant forms of the virus.

From the analysed data, it was discovered that $2.5 \%$ of the respondents' agreed that their treatment plan is difficult to follow which in one way or the other affected their adherence to the drugs which was supported by Ojukwu (2019). who stated that complexity of medication regimen is one of the factors that contribute to the non-adherence of patients to their antiretroviral therapy.

In the study, $7.5 \%$ of the respondents are affected by the drug when thy take them and $92.5 \%$ are not. $100 \%$ of

the respondents are not scared of the side effects of the drugs when they take them. $12.5 \%$ of the respondents sometimes, forget to take their drugs and $87.5 \%$ do not forget. 2.55 of the respondents opined that the drugs are too many and $97.5 \%$ doesn't think the drugs are too many. $95 \%$ of the respondents agreed that the ART clinic is accessible and 55 of the respondents think the clinic is not accessible. Transport cost to ART clinic is affordable for $97.5 \%$ of the respondents and unaffordable for $2.5 \%$ of the respondents. $100 \%$ of the respondents agreed that the physical environment of the clinic is neat and welcoming. $17.5 \%$ of the respondents do not want to be seen at the clinic and $82.5 \%$ doesn't mind to be seen $100 \%$ of the respondents disagreed that the nature of their work has not been giving them enough time to attend the clinic. While, $2.5 \%$ of the respondents said that the workers are not accommodating, $97.5 \%$ of the respondents opined that the workers are accommodating. This finding was in congruence with that observed in the study by Mitiku, Ahmed, \&Teklemariam, (2013) on people living with human immunodeficiency virus (HIV) and attending the ART service at HiwotFana and Jugal hospitals where the main reasons for non-adherence were forgetting (47.2\%), traveling (18.9\%), and being busy doing other things $(15.1 \%)$. There was not any independent predicator identified for adherence to ART. Similarly, the findings of the study conducted by Okoronkwo, et al (2013) showed that the commonest occurring factors of non-adherence were forgetfulness $(53.8 \%)$, busy schedule $(38.8 \%)$, side effects of drugs (31.9\%), and stigma (31.9\%). In keeping with this findings also was that observed in the study by Dominic et al (2018) where they discovered that poor adherence to long term ART was due to: travel for work or social activities, stigma, receiving little or no continuous ART adherence education, alcohol consumption and use of alternative 'HIV cure' medicines. Other reasons included; ART side effects, treatment fatigue, belief that long-term ART or God can cure HIV and food security. These findings were also in agreement with those observed in the study by Shukla, Agarwal, Singh, et al (2016) in District of Northern India where the principal causes cited were being busy with other work (40.0\%), felt sick or ill $(28.5 \%)$, not having money $(14.2 \%)$, and being away from home $(11.4 \%)$.

It was also observed in the current study that there was a significant relationship between level of education and perception about antiretroviral therapy $(\mathrm{df}=4, \mathrm{P}<0.001)$. This 
was expected because education can shape an individual view of certain aspects of life including health. This finding was in keeping with that observed in the study by Desta, Biru, \& Kefale, (2020). where there level of education of respondents had strong correlation with their knowledge and perception about antiretroviral therapy. It was also observed in the current study that there was a significant relationship between perception and compliance with antiretroviral therapy $(\mathrm{df}=1$, $\mathrm{P}<0.001)$. This as in keeping with the finding of the study by Stricker, Fox, Baggaley, et al. (2014). where knowledge and compliance were closely associated in terms of antiretroviral drug.
[15] in Care and Adherence to ART are Critical Elements of HIV Care Interventions. AIDS Behav 18, 465-475 (2014). https://doi.org/10.1007/s10461-013-0598-6

[16] UNAIDS (2020). UNAIDS report on the global AIDS epidemic www.unaids.org > resourcesm presscentre $>2020>$ july

[17] UNAIDS (2016). Global AIDS Update 2016.www.unaids.org > default > files media asset. Rerieved April, 2021

[18] J. van Paasschen, F. Bacci, and D.P. Melcher (2015) The

[19] Influence of Art Expertise and Training on Emotion and Preference Ratings for Representational and Abstract Artworks. PLoS ONE 10(8): e0134241. https://doi.org/10.1371/journal.pone.0134241

[20] D.E. Wilson(2020) History and epidemiology of laboratory-

[21] acquired infections in Microbiological and Biomedical Laboratories 5th Edition21-1112 . 13 May 2020. Retrieved April 2021. www.utep.edu > orsp > _Files docs > BMBL

\section{RECOMMENDATIONS}

Having carefully assessed the level and factors affecti: the compliance to antiretroviral therapy by HIV/AII patients attending ART clinic in University of Medic Sciences Teaching Hospital, Akure. It is here recommended that:

1. Nurses and counselor at HIV clinics need to engage Hl positive patients in detailed education and enlightenme about their health condition and the need to be compliant wi treatment, emphasizing the benefits of compliance to them.

\section{REFERENCES}

[1]S. Clutter, M. R. Jordan, S. Bertagnolio, andR. W. Shafer, (2016 August). HIV-1 drug resistance and resistance testing. Infection, genetics and evolution: journal of molecular epidemiology and evolutionary genetics in infectious diseases, 46, 292-307. https://doi.org/10.1016/j.meegid.2016.08.031

[2]A. Desta, T.T. Biru, and A.T. Kefale, (2020). Health related quality of life of people receiving highly active antiretroviral therapy in Southwest Ethiopia, https://doi.org/10.1371/journal.pone.0237013

[3]P. Masikini, and B. C. Mpondo (2015). HIV drug resistance mutations following poor adherence in HIV-infected patient: a case report. Clinical case reports, 3(6), 353-356. https://doi.org/10.1002/ccr3.254

[4] Mitiku, T.A. Ahmed, andZ. Teklemariam (2013, August). Factors Affecting Adherence to Antiretroviral Treatment in Harari National Regional State, Eastern Ethiopia. August,2013,ISRN AIDS 2013(5):960954,DOI:

$10.1155 / 2013 / 960954$ PubMedwww.researchgate.net > publication > 256838475

[5]M. Mehari, N. Kiros, A. Yemane, N. Asghedom, S. Debesay and T. Tekeste (2017). Factors Affecting Treatment Adherence among HIV Positive Patients in Eritrea. IBBJ Summer 2017 Vol 3, No 3 ibbj.org > article-1-117-fa

[6]J. Nega, S. Taye, Y. Million, et al. (2020) Antiretroviral treatment failure and associated factors among HIV patients on first-line antiretroviral treatment in Sekota, northeast Ethiopia. AIDS Res Ther 17, 39 (2020). https://doi.org/10.1186/s12981-020-00294-Z

[7]Okoronko, U. Okeke, A. Chinweuba and P. Iheanach (2013). Non-adherence Factors and Sociodemongraphic Characteristics of HIV-infected Adults Receiving Antiretroviral Therapy in Nnamdi Azikwe University Teaching Hospital, Inewi, Nigeria, International

[8]Scholarly Research Notices, Vol.2013, Article ID 843794, https://doi.org/10.1155/2013/843794

[9]C.L. Ojukwu (2019). Effects of Nonadherence to HIV/AIDS Drugs on HIV-Related Comorbidities in Eastern Nigeria. Warden University Scholars collection

[10] R. Shigdel, E. Klouman, A. Bhandari and L.A. Ahmed (2014).

[11] Factors Associated with Adherence to Antiretroviral Therapy in HIV-infected patients in Kathmandu District, Nepal, HIVAIDS(Auckl). 2014:6:109-116 https://doi.org/.2147/HIV.S55816

[12] M. Shukla, M. Agarwal, J.Singh andK. Singh, (2016).

[13] Nonadherence to Antiretroviral Therapy Among People Living with HIV/AIDS Attending Two Tertiary Care Hospitals in District of Northern India. February 2016, Indian Journal of Community Medicine 41(1):55. DOI: 10.4103/0970-0218.170970

[14] S.M. Stricker, K.A. Fox, R.Baggaley, et al. (2014). Retention
Mary Idowu Edward holds a $\mathrm{PhD}$ degree in Nursing Education from University of Ibadan, Ibadan Oyo State, .Nigeria. Presently I work with Faculty of Nursing Science, University of Medical Sciences, Ondo State, Nigeria as a Lecturer and Coordinator of Adult Health Department/Mental Health Nursing Department. I have cognate experiences in Nursing fields such as Nursing Education, Nursing Administration, Reproductive Health, Medical Surgical Health Nursing, Mental health Nursing and Research. I have various Academic Research publications in these areas.



Folakemi Beatrice Adumaza is a registered nurse, midwife and public health nurse. I obtained my BNSc in Nursing at Obafemi Awolowo University Ile Ife Osun State. I am currently undergoing Masters program in Adult Health Nursing at Babcock University Ilishan Ogun State. I work as a Certified Adherence Counselor at both Adult pick up Center and Elimination of Mother to Child Transmission of HIV/AIDs (EMTCT). Also a Clinical instructor at Faculty of Nursing service, University of Medical sciences Ondo, Ondo State

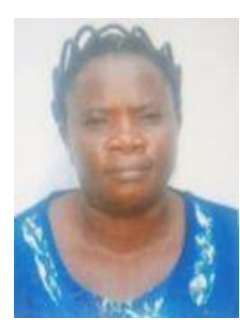

Esther OlayinkaAWOSIKAis a registered urse, Midwife, Public Health Nurse and Irse Educator. I obtained my BNSC in rsing at Ladoke Akintola University of chnology Ogbomoso, Oyo state. and PGDE OAU Ile Ife Osun State and I am currently dergoing Masters program in mental health ırsing at Nnamdi Azikiwe University Awka. m a Nurse Tutor in Institute of Professional ursing and Midwifery Education Department

University of Medical Sciences, Akure ımpus, Ondo State

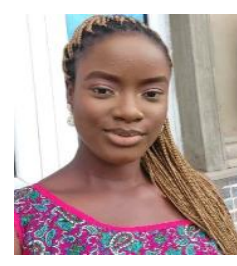

Atilola Oluwatobi ADEKUNLE is a Registered Nurse (RN) with Nigeria Nursing and Midwifery Council of Nigeria. I am currently undergoing A BNSc.Degree Program in Ladoke AkintolaUniversity, Osun State, Nigeria 